University of Nebraska - Lincoln

DigitalCommons@University of Nebraska - Lincoln

Faculty Publications from the Harold W. Manter Laboratory of Parasitology

4-1974

More Information on the Coccidian Parasites (Protozoa:

Eimeriidae) of the Colorado Pika, Ochotona princeps, with a Key to the Species

Donald W. Duszynski

University of New Mexico, eimeria@unm.edu

Follow this and additional works at: https://digitalcommons.unl.edu/parasitologyfacpubs

Part of the Parasitology Commons

Duszynski, Donald W., "More Information on the Coccidian Parasites (Protozoa: Eimeriidae) of the Colorado Pika, Ochotona princeps, with a Key to the Species" (1974). Faculty Publications from the Harold W. Manter Laboratory of Parasitology. 119.

https://digitalcommons.unl.edu/parasitologyfacpubs/119

This Article is brought to you for free and open access by the Parasitology, Harold W. Manter Laboratory of at DigitalCommons@University of Nebraska - Lincoln. It has been accepted for inclusion in Faculty Publications from the Harold W. Manter Laboratory of Parasitology by an authorized administrator of DigitalCommons@University of Nebraska - Lincoln. 


\section{MORE INFORMATION ON THE COCCIDIAN PARASITES (PROTOZOA: EIMERIIDAE) OF THE COLORADO PIKA, Ochotona princeps, WITH A KEY TO THE SPECIES}

DONALD W. DUSZYNSKI, Department of Biology, University of New Mexico, Albuquerque, New Mexico 87131, U.S.A.

Abstract: The prevalence of 7 species of Coccidia is reported from 137 Colorado pikas, Ochotona princeps, collected on Mt. Evans, Clear Creek County, Colorado, during the summers of 1968, 1969, and 1971. Identification of the parasites was based on the structure of the unsporulated oocysts which, at least for those species that have been described to date from North American pika hosts, are highly distinctive for most species. Photographs illustrate the differences in size, shape, and form of the oocysts of the various species. A key to the Coccidia of pikas, based on the descriptions of sporulated oocysts, is presented.

\section{INTRODUCTION}

Not until 1970 were coccidian parasites first reported from pikas (Ochotona princeps) in North America. ${ }^{1}$ Since then, six distinct Eimeria spp. and one Isospora sp. have been described from these hosts on this continent. ${ }^{3,4,7,8}$ Also, 2 other Eimeria spp. and another Isospora sp. have been recently observed from the collared pika $O$. collaris in the Yukon Territory, Canada, and from the Japanese pika, $O$. hyperborea yesoensis in northern Japan. 1 In July, 1972, I received 137 carcasses of $O$. princeps which had been collected in Colorado between 1967-1971 to study their reproductive biology. After each animal died or was killed and its reproductive tract had been removed, the remainder of the carcass, including the gut, was kept frozen until I received it. Prolonged freezing kills most coccidian oocysts before they can sporulate, and with the exception of a few sporulated $I$. marquardti and some partially sporulated E. klondikensis, all other oocysts which I observed in these samples were unsporulated, and presumably dead. Oocyst size and shape have been used in the past as the sole criteria for recognition of species of
Coccidia. In recent years, however, this practice has been considered unsatisfactory by most investigators, particularly those working with poultry and rabbits, since many of the Coccidia which parasitize these animals are structurally indistinguishable from each other, ${ }^{2,8,9}$ Most coccidia reported from pikas in Canada and the U.S.A., on the other hand, are distinctly different in size, shape, and other features of oocyst structure. , $^{3,4,5,7,8}$

This study was undertaken to distinguish the various species of Coccidia parasitizing the Colorado pika, based entirely on the distinctiveness of their unsporulated oocysts.

\section{MATERIALS AND METHODS}

When they were received in Albuquerque the carcasses were thawed, the entire gut from the stomach to the anus was removed and slit lengthwise, and the intestinal contents were scraped into petri dishes and then prepared (mixed, incubated, filtered, etc.) as previously described. ${ }^{3}$ Oocysts were also studied and photographed as described elsewhere. ${ }^{3}$ All measurements are in microns with the means given in parentheses following the ranges.

1 These species are described in a paper recently submitted to the Canadian Journal of Zoology by R. P. Hobbs and W. M. Samuel (see reference 5). The paper is now in review and the authors were kind enough to send me a copy of the unpublished manuscript. 


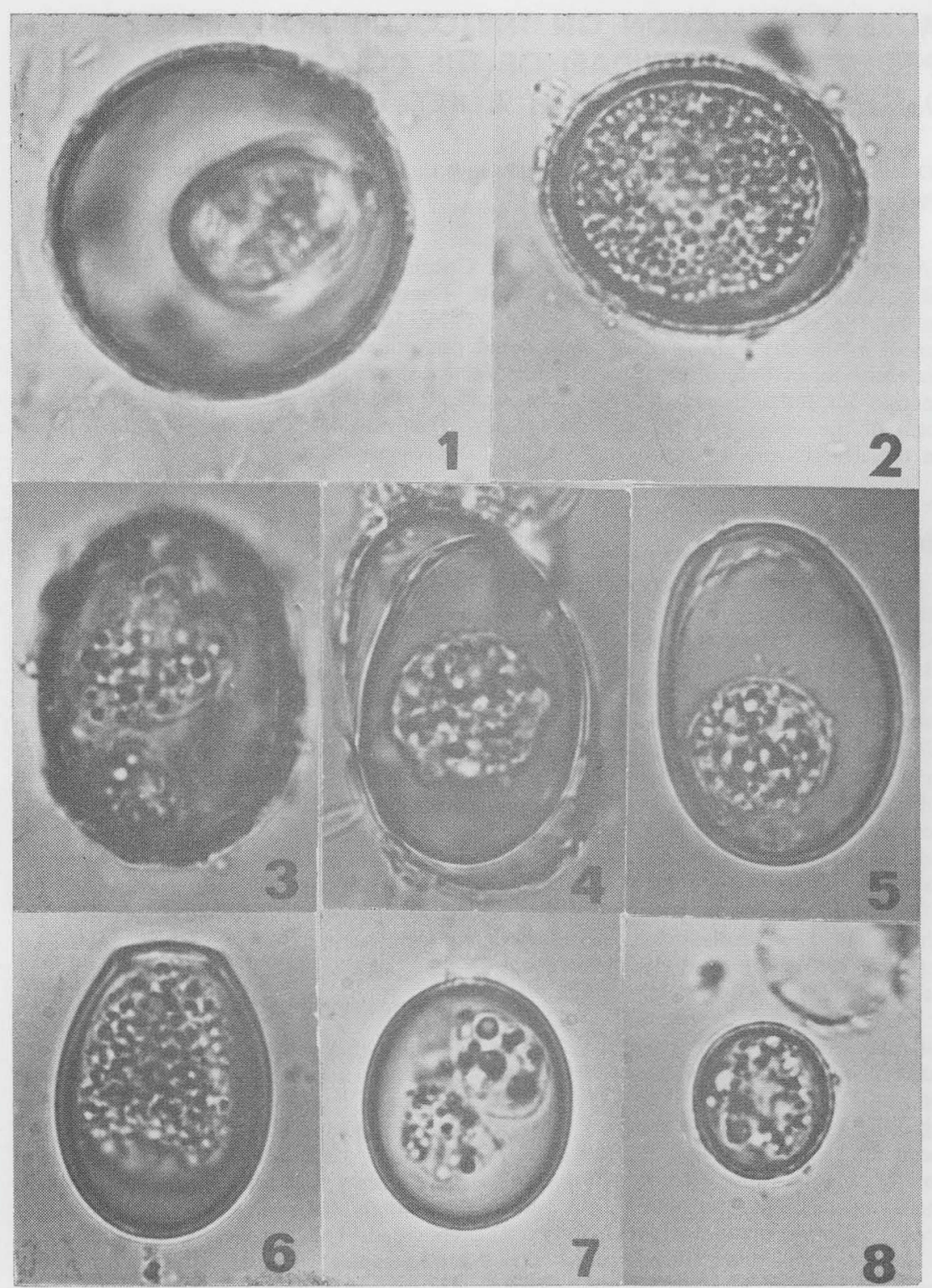

Figures 1-8. Unsporulated oocysts from Ochotona princeps. X 2000.

Fig. 1. Isospora marquardti. Fig. 2. Eimeria banffensis. Figs. 3-5. E. cryptobarretri. 3, oocyst with rough outer wall intact; 4 , outer wall breaking off; 5 , oocyst with outer wall completely removed. Fig. 6. E. calentinei. Fig. 7. E. princepsis. Fig. 8. E. worleyi. 


\section{RESULTS AND DISCUSSION}

Seven distinctly different types of oocysts were observed in the fecal material from pikas collected between 1967 1971 on Mt. Evans, Clear Creek County, Colorado (Figs. 1-11), and all were identified as species already or soon to be described from sporulated oocysts., ${ }^{3,4}$, $5,7,8,9$ Information on the prevalence of infection with each species, during each year of collection is summarized in Table 1.

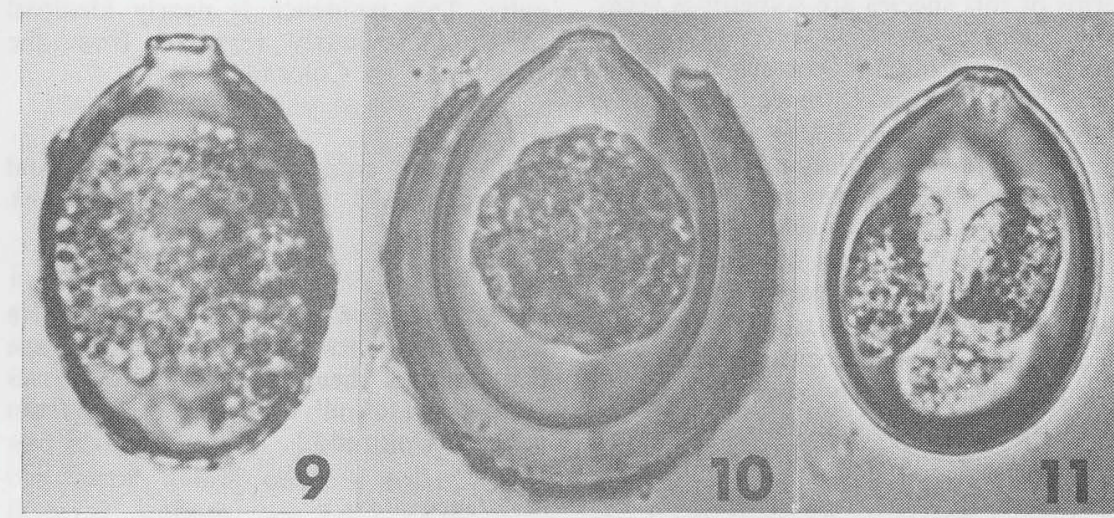

Figures 9-11. Unsporulated oocysts from Ochotona princeps. X 2000.

Figs. 9-11. Eimeria klondikensis. 9, oocyst with prominent micropyle and rough outer wall intact; 10, outer wall breaking off; 11, oocyst at 4-sporoblast stage with outer wall completely removed.

TABLE 1. Prevalence of $7 \mathrm{spp}$. of Coccidia infecting Ochotona princeps collected on Mt Evans, Clear Creek County, Colorado, 1967-1971, based on the structure of unsporulated oocysts.

\begin{tabular}{|c|c|c|c|c|}
\hline & $1967(39 *)$ & $1968(11 *)$ & $1971(87 *)$ & \\
\hline Coccidian spp. & $\begin{array}{l}\text { No. infected/ } \\
\% \text { of total }\end{array}$ & $\begin{array}{l}\text { No. infected/ } \\
\% \text { of total }\end{array}$ & $\begin{array}{l}\text { No. infected/ } \\
\% \text { of total }\end{array}$ & Totals \\
\hline Isospora marquardti & $7 / 18 \%$ & $1 / 9 \%$ & $8 / 9 \%$ & $16 / 11.7 \%$ \\
\hline Eimeria banffensis & $14 / 36 \%$ & $3 / 27 \%$ & $16 / 18 \%$ & $33 / 24.1 \%$ \\
\hline E. calentinei & $9 / 23 \%$ & $7 / 64 \%$ & $19 / 22 \%$ & $35 / 25.6 \%$ \\
\hline E. cryptobarretti & $28 / 72 \%$ & $3 / 27 \%$ & $59 / 68 \%$ & $90 / 65.7 \%$ \\
\hline E. princepsis & $27 / 69 \%$ & $7 / 64 \%$ & $48 / 55 \%$ & $82 / 59.9 \%$ \\
\hline E. worley $i$ & $12 / 31 \%$ & $3 / 27 \%$ & $10 / 11 \%$ & $25 / 18.3 \%$ \\
\hline E. klondikensis 1 & $10 / 26 \%$ & $1 / 9 \%$ & $20 / 23 \%$ & $31 / 22.6 \%$ \\
\hline uninfected hosts & $0 / 0 \%$ & $0 / 0 \%$ & $6 / 7 \%$ & $6 / 4.4 \%$ \\
\hline
\end{tabular}

*No. of hosts collected that year. 
Isospora marquardti Duszynski and Brunson, 1972

Remarks

(Fig. 1)

The unsporulated oocysts of this species were identical to those in the original description. ${ }^{3}$ Although subspherical forms of this species are sometimes seen, ${ }^{3}$ only oocysts which were absolutely round and within the correct size range were identified as $I$. marquardti. It is interesting to note that sporulated oocysts were seen in some of the samples even though they had been frozen for 2-5 years. Three possible explanations exist: 1) these oocysts may have sporulated within the gut of the host and were then able to withstand the extended freezing; 2) the unsporulated oocysts of this species may be extremely resistant to cold and were able to sporulate when the animals were thawed and the fecal material was incubated in this laboratory (5 days at 22C); or 3 ) since the hosts are coprophagus, sporulated oocysts may have been ingested with their own feces or with that from other hosts sometime shortly before their death. The latter alternative seems most likely because, in general, sporulated oocysts tend to be more resistant to freezing than do unsporulated ones. ${ }^{\circ}$

\section{Prevalence}

This species was found in 16 of the $137(11.7 \%)$ pikas examined for Coccidia.

Eimeria banffensis Lepp, Todd and Samuel, 1973

(Fig. 2)

Remarks

Oocysts of this species have been described twice. ${ }^{4,8}$ From the information available, the oocyst wall somewhat resembles that of 1 . marquardti. However, unsporulated oocysts of this species can be easily distinguished from those of $I$. marquardti in that they are slightly smaller and are almost always subspherical. Of the oocysts which I observed, only those which were subspherical and fit within the size ranges reported from hosts in Colorado were assigned to this species.

\section{Prevalence}

This species was found in 33 of the $137(24.1 \%)$ pikas examined for Coccidia. This incidence is nearly identical to that previously reported from the same host in Colorado.

Eimeria calentinei Duszynski and Brunson, 1973

\section{Remarks}

(Fig. 6)

The presence of a distinct micropyle as well as characteristic size and shape distinguishes the oocysts of this species from those of all others described from pikas in Colorado.

\section{Prevalence}

This species was found in 35 of the $137(25.6 \%)$ pikas examined for Coccidia. In a previous report, ${ }^{4} 0$ of 14 hosts collected on Mt. Evans during July and August, 1970, harbored this parasite although 4 of 12 hosts (33\%) collected from Crown Point in Larimer County were infected at the time of sampling.

Eimeria cryptobarretti Duszynski and Brunson, 1973

\section{Remarks}

$$
\text { (Figs. 3, 4, 5) }
$$

When completely intact, the rough outer wall of this species (Fig. 3) is sufficient to distinguish it from the oocysts of all other coccidia reported from pikas. During processing, however, this outer wall sometimes breaks off (Fig. 4) leaving an oocyst which, when unsporulated (Fig. 5), is very similar to those described for E. barretti ${ }^{1,7}$ In the first report of coccidia from the Colorado pika collected on Mt. Evans in 1970, I never saw a sporulated oocyst identifiable as $E$. barretti although 17 of $30(57 \%)$ hosts harbored E. cryptobarretti. ${ }^{4}$ Therefore, only oocysts with their 
completely intact rough outer wall were identified as $E$. cryptobarretti in this study.

\section{Prevalence}

This species was found in 90 of the $137(65.7 \%)$ pikas examined for Coccidia.

Eimeria klondikensis Hobbs and Samuel, 19741

\section{Remarks}

(Fig. 9-11)

The following descriptive features are included here because they either add supportive data or are not included in the original description of this parasite. ${ }^{5}$ Oocysts ovoid; oocyst wall $\sim 2.2$, consisting of 2-3 layers: outer layer brown and rough (Fig. 9) $\sim 1$ thick, usually has some debris clinging to it; inner layer(s) smooth, $\sim 1-1.5$ (Fig. 11); distinct micropyle $\sim 5$ wide, in raised position $\sim 3$ above oocyst wall; unsporulated oocysts $(\mathrm{n}=10) 34$ to 39 by 29 to 33 ( 36.5 by 30.7$)$, with shape indices 1.07 to $1.29(1.19)$.

The size, shape, and presence of a distinct, elevated micropyle distinguish oocysts of this species from all others described from pikas., ${ }^{3,4,5,7,8,9}$ Although partially sporulated oocysts were sometimes seen, completely sporulated ones were not. Attempts at incubating oocysts (10 days at $22 \mathrm{C}$ ) to allow development to continue beyond the 4-sporoblast stage (Fig. 11) were unsuccessful.

\section{Prevalence}

This species was found in 31 of the $137(22.6 \%)$ pikas examined for Coccidia.

Eimeria princepsis Duszynski and Brunson, 1973

(Fig. 7)

Remarks

The size and shape of oocysts of this species are unique among the Coccidia described from pikas in Colorado. ${ }^{4}$ The unsporulated oocysts identified as $E$. princepsis were all within the size range previously reported. ${ }^{4}$

\section{Prevalence}

This species was found in 82 of the $137(59.9 \%)$ pikas examined for Coccidia.

Eimeria worleyi Lepp, Todd and Samuel, 1972

\section{Remarks}

(Fig. 8)

This species has the smallest oocyst of all the Coccidia which infect pikas, ${ }^{7}$ and for this reason the oocyst, whether or not it is sporulated, cannot be mistaken for any other type.

\section{Prevalence}

This species was found in 25 of the $137(18.3 \%)$ pikas examined for Coccidia.

Key to the Species of Coccidia in Pikas Based on Structure of Sporulated Oocysts:

1. Oocyst with 2 sporocysts, genus Isospora ……......................................... 2

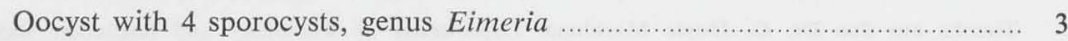

2. Oocyst round or nearly so I. marquardti Oocyst elongate ellipsoid I. yukonensis 1

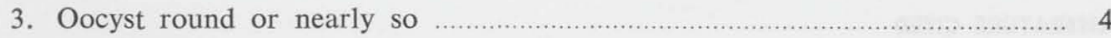
Oocyst subspherical, ovoid, or ellipsoid ……...............................................

4. Oocyst 15-22, sporocysts ellipsoid, sporocyst residuum absent ........... E. shubini Oocyst $<15$, sporocysts ovoid, sporocyst residuum present

E. worleyi 


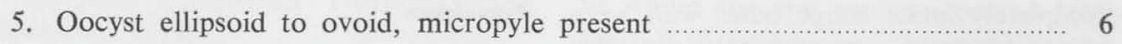

Oocyst without micropyle …….............................................................. 12

6. Oocyst with distinct elevated micropyle about 3 above level of oocyst wall ....................................................................... E. klondikensis ${ }^{[1}$

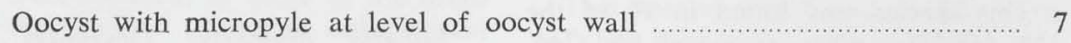

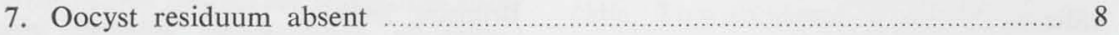

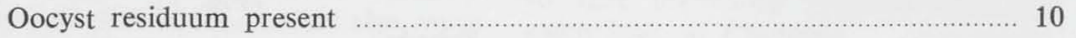

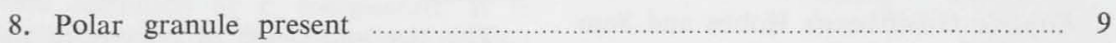

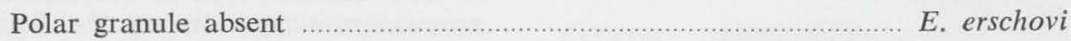

9. Polar granule a compact body about 4 , sporocyst residuum diffuse, sporozoites with single refractile body

E. barretti

Polar granule characteristically diffuse, sporocyst residuum compact, sporozoites with 2 refractile bodies ................................. E. circumborealis 1

10. Oocyst usually $>26$ long, sporocyst residuum present, Stieda body present

E. calentinei

Oocyst usually $<26$ long 11

11. Sporocyst small, $<9$ long, sporocyst residuum absent

E. ochotona

Sporocyst large, $>9$ long, sporocyst residuum present

E. metelkini

12. Oocyst with polar granule, oocyst residuum absent 13

Oocyst without polar granule

13. Sporocyst residuum absent E. pallasi Sporocyst residuum present

14. Oocyst usually $>23$ long, sporocyst residuum present, Stieda body present, substiedal body present

E. banffensis

Oocyst usually $<23$ long, sporocyst residuum present, Stieda body present, substiedal body absent

E. princepsis

15. Oocyst $>24$ long with outer wall very rough and easily separated from smooth inner wall

E. cryptobarretti

Ooocyst $<24$ long with outer wall smooth, probably only single layer to oocyst wall

E. daurica

\section{Acknowledgements}

Thanks are due Dr. O. Doyle Markham, Department of Radiology and Radiation Biology, Colorado State University, for supplying the hosts used in this study and to Dr. W. M. Samuel and Mr. R. P. Hobbs, Department of Zoology, University of Alberta for their cooperation.

\section{LITERATURE CITED}

1. BARRETT, R. E. and D. E. WORLEY. 1970. Parasites of the pika (Ochotona princeps) in two counties in Southcentral Montana, with new host records. Proc. Helm. Soc. Wash. 37: 179-181. 
2. DUSZYNSKI, D. W. and W. C. MARQUARDT. 1968. Eimeria (Protozoa: Eimeriidae) of the cottontail rabbit Sylvilagus audubonii in northeastern Colorado, with descriptions of three new species. J. Protozool. 16: 128-137.

3. DUSZYNSKI, D. W. and J. T. BRUNSON. 1972. The structure of the oocyst and the excystation process of Isospora marquardti sp. n. from the Colorado pika, Ochotona princeps. J. Protozool. 19: 257-259.

4. DUSZYNSKI, D. W. and J. T. BRUNSON. 1973. Structure of the oocysts and excystation processes of four Eimeria spp. (Protozoa: Eimeriidae) from the Colorado pika, Ochotona princeps. J. Parasitol. 59: 28-34.

5. HOBBS, R. P. and W. M. SAMUEL. 1974. Coccidia of pikas with specific reference to Ochtona collaris, $O$. princeps and $O$. hyperborea yesoensis. Can. J. Zool. 52: (in review).

6. KHEYSIN, Y. M. 1972. Life Cycles of Coccidia of Domestic Animals. (K. S. Todd, ed.). Univ. Park Press, Toronto.

7. LEPP, D. L., K. S. TODD, JR. and W. M. SAMUEL. 1972. Four new species of Eimeria (Protozoa: Eimeriidae) from the pika Ochotona princeps from Alberta and O. pallasi from Kazakhstan. J. Protozool. 19: 192-195.

8. LEPP, D. L., K. S. TODD, JR. and W. M. SAMUEL. 1973. Eimeria banffensis n. sp. (Protozoa: Eimeriidae) from the pika Ochotona princeps from Alberta. Trans. Amer. Micr. Soc. 92: 305-307.

9. PELleRdy, L. P. 1965. Coccidia and Coccidiosis. Hungarian Acad. Sci., Budapest. 